\title{
Medical Liability: The Current State of Italian Legislation
}

\author{
Alessandro Feola, ${ }^{,},{ }^{\prime}$ Valeria Marino ${ }^{2}$ and Luigi T. Marsella ${ }^{3}$ \\ ${ }^{1}$ Department of Experimental Medicine, Second University of Naples, Naples, Italy \\ ${ }^{2}$ Section of Legal Medicine, University of Rome 'Tor Vergata', Rome, Italy \\ ${ }^{3}$ Department of Biomedicine and Prevention, University of Rome 'Tor Vergata', Rome, Italy
}

\begin{abstract}
The professional liability of healthcare professionals is a decidedly current issue. In the past decade, litigation for alleged medical malpractice incidents has increased exponentially in Europe. In Italy, the last 20 years have been witness to significant upheavals in this sense. In this article, we analyse the evolution of professional liability legislation in Italy, as well as addressing, in some detail, the changes introduced by Law 189/2012, with which the Italian legislators radically revolutionized the medical liability sector. Particular attention is dedicated to the jurisprudential developments most affected by this reform.
\end{abstract}

\section{Keywords}

medical liability; medical malpractice; litigation; tort

\section{Introduction}

The professional liability of healthcare professionals is a decidedly current issue; indeed, in the past decade litigation regarding alleged medical malpractice has increased exponentially in Europe. ${ }^{1}$ Substantial changes have occurred in the context of medical liability legislation in Italy with the coming into force of Law no. 189/2012, also known as the 'Balduzzi Law'. Article 3 of this law states that "the healthcare professional who, in carrying out his/her professional activities, adheres to the guidelines and best practices accredited by the scientific community, cannot be held criminally liable for malpractice, whilst the obligation for compensation, as defined in article 2043 of the Civil Code, persists. The judge shall also take due account of the standard of conduct denoted above when determining eventual compensatory damages". ${ }^{2}$ This article also establishes a special concession system for the liability insurance of medical professionals. The quantification of compensation for biological damages is based on the tables of Articles 138 and 139 of the Insurance Code, whose applicability was originally restricted to compensation for injuries caused by road traffic accidents. Since the emission of the new law, two key issues have been subject to criticism: first, the scope of the legislation, given the fact that it confers a certain degree of criminal liability to individual healthcare professionals, and second, the specific reference to Article 2043 of the Italian Civil Code. The present article will mainly focus on the latter, attempting to outline the essence of medical liability in the context of civil law in view of the numerous rulings issued since the introduction of the new legislation. This topic has attracted new interest following a recent

* Corresponding author: alessandro.feola@unina2.it.

${ }^{1}$ S.D. Ferrara, G. Viel and R. Boscolo-Berto, 'Present and future for medical malpractice, responsibility and liability', in: S.D. Ferrara, R. Boscolo-Berto and G. Viel (eds.), Malpractice and Medical Liability. European State of the Art and Guidelines (Berlin-Heidelberg: Springer-Verlag, 2013) pp. 3-9.

${ }^{2}$ Article 2043 of the Civil Code: 'Compensation for unlawful acts: Any intentional or negligent act that causes an unjustified injury to another obliges the person who has conmitted the act to pay damages'. 
judgement (17 July 2014) by the Court of Milan.

\section{Legislation Overview}

Prior to 1999 , the admission of a patient to a healthcare facility entailed formulating an admission contract, or a contract for professional services between the patient and the facility. In this regard, the legislation stated that "the responsibility of the healthcare professional towards the patient for damages caused by individual diagnostic or therapeutic errors shall only be considered extracontractual, and consequently compensation claims by the patient have a five-year limitation period as established by the first paragraph of Article 2947 of the Civil Code". ${ }^{3}$ Another approach was proposed promoting the contractual liability of both the healthcare facility and the individual physician. ${ }^{4}$ Several arguments supporting the contractual nature of the liability of individual healthcare professionals have since been highlighted. It was considered more fitting to establish a contract with protective effects in favour of a third party, as the contract between the healthcare facility and the individual physician would subsequently cover the care of patients requiring their services. ${ }^{5}$ However, the latter approach attracted further criticism, specifically that patients affected by a breach of duty were not entitled to claim damages under such contracts in favour of a third party. Instead, patients had to claim under the separate contract for professional services stipulated between the patient and the facility. Because of this criticism another scheme was introduced, consisting of 'liability arising from a qualified social contact': "liability arising from the duty without a primary obligation of performance". ${ }^{6}$ Finally, in the further evolution of the "qualified social contact' approach, the liability of the physician was considered, as confirmed by the $3^{\text {rd }}$ Civil Chamber of the Court of Cassation (no. 8826/2007), "a performance that is modelled on the contract for the provision of professional services, according to which the physician is required to carry out his/her professional activity within the facility with which the patient has stipulated a contract, with the various associated obligations of conduct, aimed at ensuring that the requisite degree of diligence is applied to safeguard any emerged or endangered interests [of the patient] in the course of the said contact, and in view of the subsequently required medical care". Simultaneously with the jurisprudential evolution driving the perception of medical liability as a liability for non-fulfilment of obligations, and thus of a contractual nature, the doctrine and jurisprudence have tackled another long-standing issue related to the distinction between 'obligation of means' and 'obligation of outcome'. The implications of these concepts are particularly significant in the medical context, especially in relation to the allocation of the burden of proof between the patient (creditor) and the physician (debtor). Obligation of means is defined as "conduct apt to set off a process of transformation, and, consequently, of conservation, whose outcome depends on several factors unrelated to the scope of duty". 7 The obligation of outcome, instead, refers to an obligation to achieve a set result, or in other words, the satisfactory fulfilment

\footnotetext{
${ }^{3}$ Court of Cassation, $3^{\text {rd }}$ Civil Chamber (no. 1716/1979).

${ }^{4}$ C. Di Marzo, 'Medical malpractice: the Italian experience', Chicago-Kent Law Review 87 (1) (2012) 54-77.

${ }^{5}$ A. Di Majo, 'La protezione del terzo tra contratto e torto', Europa e diritto privato 1(1) (2000) 1-26.

${ }^{6}$ Court of Cassation, $3^{\text {rd }}$ Civil Chamber (no. 589/1999); A. Di Majo, 'L'obbligazione senza prestazione approda in Cassazione', il Corriere Giuridico (4) (1999) 446-451; E. Guerinoni, 'Obbligazione da "contatto sociale" e responsabilità contrattuale nei confronti del terzo', I Contratti (11)(1999) 999-1013; The concept of contract with protective effects in favour of third parties has been developed by German courts, having recourse to a doctrine called Vertrag mit Schunzwirkung fur Dritte, in C. Di Marzo, 'Medical malpractice: the italian experience', Chicago-Kent Law Review 87 (1) (2012) 54-77.

${ }^{7}$ L. Mengoni, 'Obbligazioni di risultato e obbligazioni di mezzi', Rivista del diritto commerciale 52(5-6) (1954) $185-$ 209.
} 
of the primary need of the creditor. ${ }^{8}$ Prior to 2001 , the prevalent jurisprudential view was that obligation of outcome should be evaluated via the regulations set out in Article 1218 of the Civil Code. Under that article, the creditor would bear the burden of proof only in cases based on contractual or obligatory duties, as well as any deadline, if stipulated, thus only being imputable for non-fulfilment. ${ }^{9}$ Obligation of means, however, was considered to fall under the provisions of the second paragraph of Article 1176 of the Civil Code, where the creditor is required to prove the inadequate performance of the debtor, in addition to providing evidence of the existence of a contract between the two parties. ${ }^{10}$ In medical liability cases, the regulations concerning obligations of means were generally applied to claims involving complex medical interventions. In contrast, those involving routine or simple procedures were evaluated on the basis of the rules on obligations of outcome. Regarding the latter, the patient just needed to prove that the treatment that had caused a deterioration in his/her condition could be considered routine in nature, thus creating a rebuttable presumption of guilt. The burden of proof was then shifted to the physician, who was required to prove that the procedure had been carried out in a satisfactory manner or the impossibility thereof. In cases involving complex interventions, and in particular those of an uncertain outcome, the physician could easily overcome the presumption of guilt by demonstrating the complexity of execution of the intervention. Thus, the burden of proof back was placed back on the patient who was then required to produce proof of the causal link between the poor outcome and treatment error." The distinction between obligation of means and obligation of outcome was repudiated by the Joint Chambers of the Court of Cassation in $2001 .{ }^{12}$ In light of this judgement, the Court of Cassation decreed that when claiming compensation for damages caused by breach of contract, the creditor need only supply proof of a contract or a social contact between the two parties. Thus, the creditor is validating his/her right to compensation, together with the contention of non-fulfilment or inadequate fulfilment. The debtor is then left with the burden of proving that his/her professional activity was carried out with due diligence, and that the damages to the patient were due to external causes. ${ }^{13}$ In consideration of the above, the potential exonerating evidence provided by the physician must be of a causal nature because it has to show that the poor outcome was caused by an external factor out of his/her control, thus disrupting the causal connection between his/her conduct and the damage to the patient. ${ }^{14}$ The Court of Cassation subsequently clarified this interpretation as follows: "the distinction between routine services and interventions requiring particularly challenging technical solutions can no longer be used as a criterion for the distribution of burden of proof, but it must be taken into consideration in the assessment of the standard of diligence and the corresponding degree of guilt, while the responsibility of proving that the intervention in question

\footnotetext{
${ }^{8}$ E. Guerinoni, 'Attività sanitarie e responsabilità civile', il Corriere Giuridico (5) (2013) 5-54.

${ }^{9} \mathrm{C}$. Vaccà, 'L'intervento di chirurgia estetica è obbligazione di risultato?', Responsabilità civile e previdenza 51(1) (1986) 46-47.

${ }^{10}$ Court of Cassation, $3^{\text {rd }}$ Civil Chamber (no. 6141/1978, no. 6220/1988).

11 Supra note 7.

${ }^{12}$ Court of Cassation, Jouint Civil Chambers (no. 1716/2001); C. Castronovo, 'Profili della responsabilità medica', in: P. Rescigno (ed.), Studi in onore di Pietro Rescigno (Milano: Giuffè̀, 1998) vol. 5 pp. 117-136; A. Nicolussi, 'Sezioni sempre più unite contro la distinzione tra obbligazioni di mezzo e di risultato. La responsabilità del medico', Danno $e$ responsabilità, 13(8-9) (2008) 871-879; U. Carnevali, 'Inadempimento e onere della prova', Contratti (2) (2002) 118 121.

${ }^{13}$ F. Busoni, L'onere della prova nella responsabilità del professionista (Milano: Giuffrè, 2011) p. 97; A. Santoro, La responsabilità da contatto sociale (Milan: Giuffrè, 2012) pp. 64-65; M.G. Corsi, 'Responsabilità della struttura sanitaria e riparto dell'onere probatorio', Giurisprudenza Italiana (2008,) 1197-2000; C. Lorè, P. Martini, Sulla responsabilità penale degli amministratori di strutture sanitarie. Retreived 12 November 2014. www.scienzemedicolegali.it/riviste/responsabilità \%20amministratori\%20strutture\%20sanitarie.html\# ftn1. ${ }^{14}$ D. Maggese, 'Probabilità scientifica e nesso di causalità tra lesione personale ed intervento chirurgico', Danno e responsabilità, 6(1) (2001) 72; A. Fiori, 'Il criterio di probabilità nella valutazione medico-legale del nesso causale', Rivista Italiana di Medicina Legale, 13(1) (1991) 29-42.
} 
was particularly complex remains on the healthcare professional.". ${ }^{15}$ Obviously, the allegation produced by the patient-claimant "cannot refer to an indiscriminate breach of duty, but only to a socalled qualified breach that is theoretically capable of producing such damage. It will be the debtor's duty to prove that no such breach took place, or, in case it did, the damage was not caused by it". ${ }^{16}$ Finally, at the end of this brief excursus, it is essential to outline the scope of action of Article 2236 of the Civil Code, which limits the liability of a professional service provider in technically challenging cases in the medical field to instances of breach of contract committed with intent or gross negligence. ${ }^{17}$ This raises the threshold of significance of the breach in cases in which the professional has been required to tackle technical problems of particular complexity. The rationale behind this provision is to reconcile two conflicting objectives: "to not stifle the initiative of the professional through fear of unjust reprisals by the client in case of failure, and, inversely, to not indulge unreasonable decisions or reprehensible inertia of the professional" ${ }^{18}$ Even though the burden of proof shifts in particularly complex cases, it remains a crucial requisite in the evaluation of any claim; in fact, in medical malpractice cases, the key criterion is that of predictability, meaning that the physician is liable for the consequences of avoidable damage that a judicious physician should have been able to foresee. ${ }^{19}$ Thus, unlike in the past, the claimant is not required to provide proof of the events that led to the injury, while the defendant needs to prove that he/she was not negligent, as well as demonstrating to have taken reasonable precautions to avoid the damaging event. $^{20}$

\section{3}

The Consequences of Law no. 189/2012

After the inevitable overhaul of the Italian medical liability legislation due to jurisprudential and doctrinal evolution, it is now time to assess the effects of the entry into force of Law no. 189/2012, also known as the 'Balduzzi Law'. Originally brought forward as the infamous Article 3 of Legislative Decree no. 158/2012, which was subsequently converted into the aforementioned law, it was worded as follows: "Subject to the provisions of Article 2236 of the Civil Code, in the assessment of malpractice by healthcare professionals, in this specific context the judge shall consider in particular the observance of guidelines and best practices accredited by the national and international scientific community, as per Article 1176 of the Civil Code". This provision would therefore have been applicable within the scope of civil law, and devoid of relevance in the context of the criminal responsibility of physicians and other healthcare professionals. During the parliamentary process, however, the content of Article 3, now Law no. 189/2012, was profoundly altered, probably owing to the pressing desire to extend its scope of application to include criminal cases, or, in fact, primarily to criminal cases, with some repercussions on civil proceedings. The provision currently in force states:

\footnotetext{
${ }^{15}$ Court of Cassation, $3^{\text {rd }}$ Civil Chamber (no. 10297/2004, no. 11488/2004).

${ }^{16}$ Court of Cassation, Joint Chambers (0.577/2008); F. Busoni, L'onere della prova nella responsabilità del professionista (Milan: Giuffrè, 2011) p. 68; R. Breda, 'La responsabilità civile dell'esercente la professione sanitaria alla luce della c.d. Legge Balduzzi: ipotesi ricostruttive a confronto', Rivista Italiana di Medicina Legale, 35(2) (2013), $751-770$.

${ }^{17}$ A. Fiori, 'La medicina legale difensiva', Rivista Italiana di Medicina Legale, 18(4) (1996), 899-910; M. Paradiso, 'La responsabilità medica: dal torto al contratto', Rivista di Diritto Civile 47(3) (2001) 325-352; P.G. Montanari, 'La responsabilità civile', in: R. Sacco (ed.), Trattato di diritto civile (Torino: UTET, 1998), p. 743; V. Zambrano, P. Stanzione, Attività sanitaria e responsabilità civile (Milano: Giuffrè, 1998), p. 85.

${ }^{18}$ Costitutional Court (no. 166/1973).

${ }^{19}$ Court of Cassation, $3{ }^{\text {rd }}$ Civil Chamber (no. 3847/2011).

${ }^{20} \mathrm{~V}$. Zambrano, Interesse del paziente e responsabilità medica nel diritto civile italiano e comparato (Napoli: ESI, 1993) p. 159.
} 
The healthcare professional who, in carrying out his/her professional activities, adheres to the guidelines and best practices accredited by the scientific community, cannot be held criminally liable for malpractice, whilst the obligation for compensation, defined in article 2043 of the Civil Code, persists. The judge shall also take due account of the conduct denoted above when determining eventual compensatory damages. [...] Compensation for biological damages resulting from the activities of the healthcare professional is determined based on the Tables of Articles 138 and 139 of the Legislative Decree no. 209/2005, possibly integrated with the procedure from paragraph 1 of Article 138, and according to the criteria described in the above Articles, to allow for circumstances not provided for by them, and pertinent to the activities referred to in the present article.

This review focuses on the contents of the second paragraph of the abovementioned article, which refers expressly to the obligations arising from Article 2043 of the Civil Code, pertaining to healthcare professionals whose conduct has complied with the guidelines and good practices endorsed by the scientific community. This section of the new law could not go unnoticed, and has sparked mixed opinions since its enactment.

1) Based on an initial interpretation, the new regulations would appear to be a radical turnaround, reinstating a configuration in which the liability of healthcare professionals can only be considered extra-contractual. This approach would be perfectly in line with the initial objectives at the base of the reform, such as contrasting the so-called defensive medicine phenomenon (i.e., practices where, to protect themselves from lawsuits by patients, physicians end up prescribing a series of unnecessary examinations and investigations with a substantial burden to the public health system) and reducing insurance costs. In the wake of this reform, the Court of Milan has considered the legislation applicable to all healthcare professionals, not just physicians, with no distinction between public and private sectors. Thus, the legitimacy of this provision has been questioned because of the marked contrast with other provisions, including Articles 3 and 28 of the Constitution, stating that physicians employed by public structures "receive a differential and fundamentally privileged treatment over all other functionaries, directors and other employees of the State and public agencies, who do not exercise a healthcare profession, but nonetheless carry out an activity that routinely affects the same legal interests (health, psychophysical integrity of the person, life, public safety, personal safety, safety of goods, provision of a public service) and are not pardoned of malpractice". ${ }^{21}$

2) Partially in line with the former, a second approach upholds the so-called twofold liability: a separate, contractual liability of the healthcare facility, and a concurrent, extra-contractual liability of the individual healthcare professional. Consequently, the facility would in general be responsible for objective liabilities, which could only be overturned by providing evidence of a circumstance out of their control, and representing the sole cause of the damage, thus conforming to the provisions of Articles 1218 and 1228 of the Civil Code. In contrast, the physician would only bear the liability in cases fulfilling all the required elements stated in Article 2043 of the Civil Code. ${ }^{22}$ The introduction of this interpretation was, however, followed by an interesting ruling by the Court of Turin, ${ }^{23}$ according to which

\footnotetext{
${ }^{21}$ Court of Milan, $9^{\text {th }}$ Penal Chamber (21 March 2013).

${ }^{22}$ R. De Matteis, 'Dall'atto medico all'attività sanitaria. Quali responsabilità?', in: S. Rodotà and P. Zatti (eds), Trattato di Biodiritto (Milano: Giuffrè, 2011) vol. IV, pp. 151-155; M. Hazan, D. Zorzit, 'Responsabilità sanitaria e funzione assicurativa: prove tecniche di interazione e coordinamento', in: F. Martini and U. Genovese (eds), La valutazione della colpa medica e la sua tutela assicurativa (Bologna: Maggioli, 2012), p. 161.

${ }^{23}$ Court of Turin, 4th Civil Chamber (17 April 2013).
} 
the regulations included in Article 2043 should be considered applicable not only to the physician, but also to the healthcare facility.

3) According to a third interpretation, also upheld by the Court of Cassation, the distinction made by the novel legislation can be considered to lack modifying power, and despite the express reference to the new regulations, the provisions of Article 1218 would continue to apply.

4) A further approach, advocated by the Court of Arezzo, ${ }^{24}$ asserts that the reference to Article 2043 should only be regarded as a reminder that even in cases where the physician's conduct is considered criminally irrelevant, the obligation to compensate damages still persists. Therefore, the reference to this article should be regarded as 'non-technical', as it would leave open to interpretation the actual scope of professional responsibility that, in light of well-established jurisprudential practices, would generally be classified as liability for nonfulfilment. ${ }^{25}$ According to the Tuscan judges, following a different reasoning would risk overstepping the scope of this provision by also applying the extra-contractual model to evident contractual infractions. ${ }^{26}$

The Judgement Released by the First Civil Chamber of the Court of Milan (17 July 2014)

The plaintiff commenced proceedings against the hospital and an individual physician employed at the facility to obtain compensation for damages caused by a total thyroidectomy carried out at the facility. In the immediate postoperative period, severe dyspnoea caused by a bilateral paralysis of the vocal cords required the patient to be treated in the intensive care unit, from which the patient was subsequently discharged. The patient was then admitted to another hospital owing to the persistence of respiratory problems, and a tracheotomy was carried out, partially resolving the damage caused by the first surgery. Subsequent specialist examinations and medico-legal evaluations revealed that the right vocal cord was paralysed and no longer recoverable, and the paralysis was acknowledged to be a direct consequence of the inappropriate intervention carried out by the cited physician, while the left vocal cord was found to have a slight margin of potential improvement with time. The plaintiff claimed that the hospital and physician were responsible for the health and moral damages suffered by him, and should therefore be required to compensate him for the said damages. The healthcare facility objected, reporting the emergence of severe unexpected difficulties during the surgery, caused by a large growth on the right side of the surgical site, affected by previous inflammatory events, and the residuum of a prior surgery of a herniated cervical disc on the left side. After two days in the intensive care unit, the surgeons and specialists recommended hospitalization at another specialist facility, where the patient underwent a temporary tracheotomy. Particularly, the defendants pleaded that the intervention should not be considered of routine nature and that the injuries reported by the patient were predictable complications of this type of surgery. Furthermore, they stated that the injuries had occurred despite the healthcare providers' diligent conduct and therefore could not constitute a liability for damages, as warranted by the limitation provided by Article 2236 of the Civil Code. At the end of the proceedings, the Court of Milan ordered the hospital and the physician to pay compensation for the damages,

\footnotetext{
${ }^{24}$ Court of Arezzo (14 February 2013).

${ }^{25}$ R. Berti, “ “Legge Balduzzi”: riforma, rivoluzione o confusione?', in: F. Martini and U. Genovese (eds), La valutazione della colpa medica e la sua tutela assicurativa (Bologna: Maggioli, 2012), p. 65.

${ }^{26}$ F. Caringella, L. Buffoni, Manuale di diritto civile (Roma: Dike, 2013) p. 673; M.G. Di Pentima, L'onere della prova nella responsabilità medica (Milano: Giuffrè, 2013); N. Todeschini, Decreto Balduzzi: alla ricerca di un senso.

Retreived 12 November 2014.

www.personaedanno.it/index.php?option=com_content $\&$ view=article\&id=42839\&catid=98.
} 
although for a lower amount than the initial demand made by the plaintiff. However, the reasoning of the judgment is extremely interesting, above all, the paragraphs in which the Court defines the nature of the responsibilities of both the healthcare facility and the physician. The judges confirm the well-established tendency according to which the configuration of the relationship between the healthcare facility, regardless of whether it is public or private, and the patient is based on an atypical contract with binding effects, known as the admission contract, and finalized by the admittance of the patient to the facility. This contract determines the obligation of the facility to provide both strictly medical services and ancillary care services. ${ }^{27}$ This clearly indicates that the facility's responsibility for non-fulfilment and/or inadequate fulfilment of the obligations covered by the admission contract should be evaluated on the basis of the provisions of Article 1218 of the Civil Code. The fact that such services are carried out by the facility's employees or contractors, and that the damage is physically caused by one of these subjects, should certainly not lead to a different conclusion. It should also be noted that Article 1228 of the Civil Code, under which the debtor is liable for intentional or negligent damages caused by third parties providing the services object of the contractual obligations, is applicable in the context of contractual liability. ${ }^{28}$ Regarding the burden of proof arising from such relationships, in view of the alleged breach of contract, the healthcare facility is required to prove to have adequately fulfilled its obligations, and that the damages reported by the plaintiff cannot be attributed to the facility. In fact, as repeatedly elucidated by the Court of Cassation, "regarding the contractual liability of the healthcare facility ... for the purpose of allocating the burden of proof the plaintiff, the affected patient, is only required prove the existence of a contract (or social contact) and the onset or aggravation of the pathology, and assert the breach of contract by the debtor, theoretically capable of causing the reported damage, whereas the debtor is required to demonstrate that such breach did not occur, or even if it did, it was not etiologically relevant". ${ }^{29}$ After defining the responsibility of the healthcare facility, the Court analysed the specific case in which the affected patient intends to indict the physician directly, deeming it of utmost importance to distinguish between cases in which the patient has stipulated a contract with the professional, and cases in which these parties have not entered into any kind of contract. In the former case, the claimant is allowed to invoke liability for non-fulfilment by the physician, as outlined by Article 1218 of the Civil Code, by producing the contract for professional services, while the actual performance or non-performance of medical-surgical service in question bears no relevance to the case. In the presence of a contract between the patient and the healthcare professional, the applicability of the first paragraph of Article 3 of Law no. 189/2012 is thus ruled out. In this passage, the Court of Milan fully endorses the previous statement of the Court of Cassation, according to which it must be excluded that Law no. 189/2012 intended to support the 'automatic' classification of medical liability as extra-contractual. ${ }^{30}$ The judges then expressly reject "the general interpretation of the second sentence of the first paragraph of Article 3 of the "Balduzzi" Law emerging from the motivations of the sentence no. 8940/2014 by the Court of Cassation - where the Court concludes that this rule should not be attributed any relevance that could lead to the rejection of the "traditional" jurisprudential view on medical liability - which seems to follow the series of interpretations that essentially tend to undermine the scope of the provision". This statement can be considered the most innovative portion of the sentence. In conclusion, the Court of Milan clearly asserts that from the first paragraph of Article 3 of the 'Balduzzi Law' transpires "the intention of the legislators to establish a liability of the physician

\footnotetext{
${ }^{27} \mathrm{G}$. Iudica, 'Danno alla persona per inefficienza della struttura sanitaria', Responsabilità civile e previdenza 66 (1) (2001) 3-12, noted that 'the public or private healthcare facility is now regarded as an actual business, and whether run for profit or non-profit, it is governed by the rules of the economy and entrepreneurship, operating within the market to offer services (of medical nature) meeting the demand of the users who require them'.

${ }^{28}$ Court of Cassation (no. 103/2011).

${ }^{29}$ Court of Cassation (no. 577/2008).

${ }^{30}$ Court of Cassation, $4^{\text {th }}$ Civil Chamber (no. 8940/2011).
} 
(and other healthcare professionals) for conducts that do not constitute a breach of a contract for professional services (separate from a contract stipulated with the facility) as tort, as per Article 2043 of the Civil Code". Therefore, the burden of proving all the elements constituting tort involving injurious damages, such as the damage (event), the causal link between the conduct of the defendant and the damaging event, the imputability for intentional damage or negligence, and the adverse financial or non-financial consequences that the damaging event has produced within the subjective legal sphere, falls on the claimant. This reduction of responsibility does not by any means extend to the healthcare facility, whose liability remains 'contractual', as per Article 1218 of the Civil Code.

\section{Conclusions}

In light of the various doctrinal and jurisprudential contributions, a fourth approach can be contemplated: the provision of the first paragraph of Article 3 of Law no. 189/2012 clearly limits its scope to cases of minor negligence, or to cases where the physician has adhered to accredited guidelines and good practices; in other words where the so-called imperizia (an unintentional failure to maintain an appropriate conduct) comes into play. Only in such cases, and where the conduct of the physician is determined criminally irrelevant, would compensatory liability (to which the legislators have arbitrarily decided to apply Article 2043 of the Civil Code) continue to subsist. However, this actually leads to unequal treatment, as this provision is applicable only in the aforementioned cases, while under different circumstances, in cases involving imprudence or gross negligence, Article 1218 of the Civil Code would be applicable. This would lead to a lack of unequivocal regulations, both in the context of contractual liability and extra-contractual liability. A literal interpretation of the current regulations would indeed seem to imply a regression into the past, but not, as maintained by some, the distant 1990s when a physician's detrimental conduct was considered to fall under extra-contractual liability. Instead, it refers to a later point in time, the era of the distinction between obligation of means and obligation of outcome, which had already seemingly been eradicated. From a thorough analysis, the new reform truly seems to have produced this effect, but with a corrective action that further accentuates the distinction previously confined within the scope of contractual liability, only affecting the assignment of the burden of proof. In the event of simple or routine interventions or treatments, Article 1218 of the Civil Code was applied, implying the liability of the physician who was therefore required to provide evidence to the contrary. In complex cases and in those involving particularly challenging technical aspects or a high risk of failure, the standard of diligence was assessed on the basis of the type of intervention. At present, the legislators seem to have on the one hand exhumed the obsolete distinction between obligation of means and outcome, and on the other emphasized this distinction even more. Thus, they have not only instituted a different procedural distribution, but have profoundly altered the legislation from both a material and a procedural point of view, as in addition to greatly increasing the burden of proof carried by the patient, they have also imposed a significantly shorter limitation period of 5 years, instead of the customary 10 -year term provided by contractual laws. 